The BDJ News section accepts items that include general news, latest research and diary events that interest our readers. Press releases or articles may be edited, and should include a colour photograph if possible. Please direct your correspondence to the News Editor, Arveen Bajaj at the BDJ, 64 Wimpole Street WIG 8YS or by email to bdj@bda.org

\section{Guide launched}

NHS Health Scotland and ASH Scotland have recently announced the launch of the Smoking Cessation Guidelines for Scotland: 2004 Update.

This replaces the earlier guidelines, which were first published in 2000, and provides the most up-to-date evidence on effective smoking cessation interventions as well as guidance on service development in Scotland.

The guidelines are for health professionals to help them support smokers who want to give up. Also available is Encouraging Smokers to Stop: What you can do.

Both documents provide guidance for providers of smoking cessation services and all health professionals who have contact with smokers during the course of their work.

Key messages from the guidelines include; all health professionals should have access to information on the smoking status of their patients, should ensure that smokers have been advised to stop and that all smokers making an attempt to stop should be strongly encouraged to use specialist smoking cessation services.

The complete set of recommendations can be found in the guidelines at: www.healthscotland.com/tobacco or www.ashscotland.org.uk.

\section{NHS \\ Health Scotland}

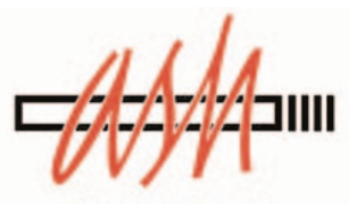

Scotland

New research

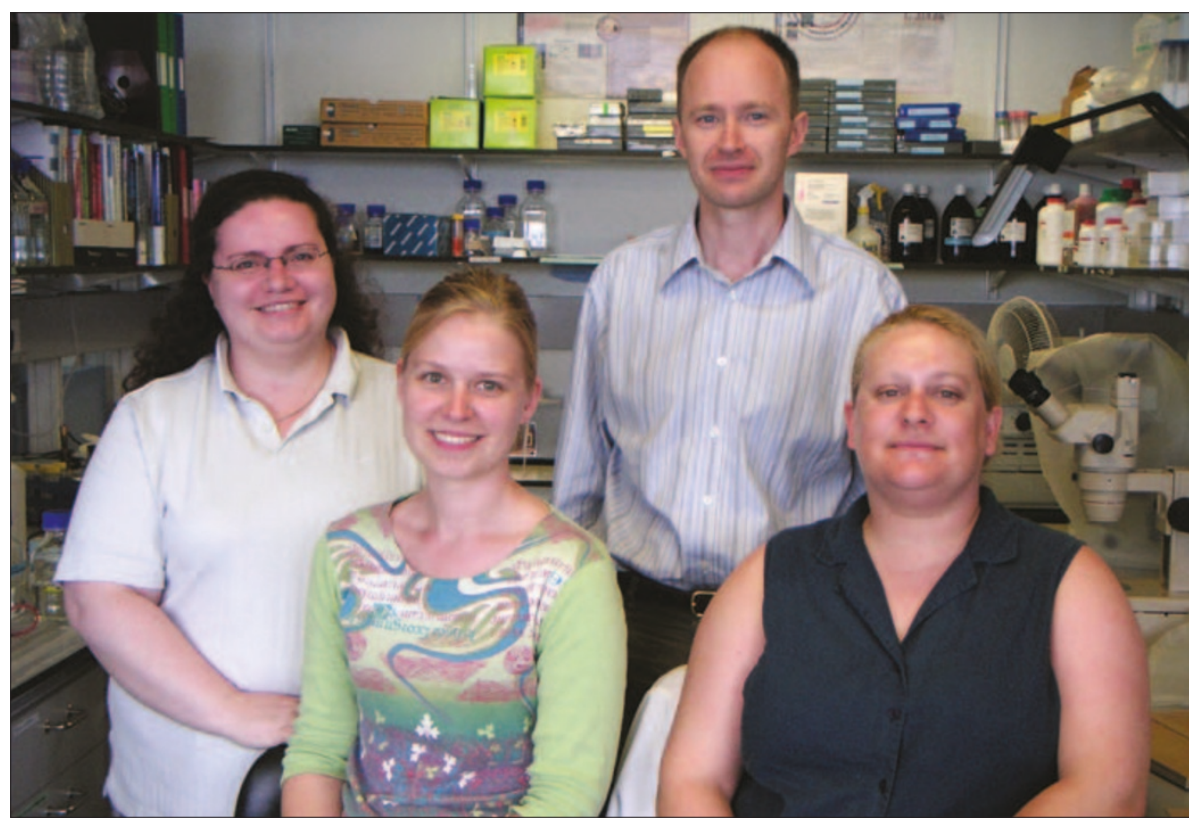

Dr David Rice and his team of researchers at the Departments of Craniofacial Development and Orthodontics (Dental Institute, King's College London) have recently taken the first crucial steps in understanding how genes that cause cleft palate interact with each other. They have investigated the very earliest stages of palate development and what happens when this process is disrupted. They discovered that a signaling molecule, fibroblast growth factor 10 ( $F g f 10$ ), is produced in the central core tissue of the palate and that it acts as a messenger sending a signal to the tissue covering the surface of the palate. According to Dr Rice, the research shows that coordinated tissue interactions are essential during the initial stages of palate development. (Journal of Clinical Investigation 2004 Jun;113 (12): 1692-700)

\title{
Boots pull out of dentistry
}

Boots Group PLC has announced that it is to pull out of its loss-making dentistry business which opened in 1999 and has 54 dental practices all over the UK.

It aims to exit from the majority of them by 31st December 2004. However, Boots will continue to provide dental treatments to existing patients during this time, though no new patients will be taken on in this period.

Together with dentistry, it will also exit from its laser eye correction, chiropody and laser hair removal businesses. It claims that despite improvements in productivity there is no prospect of the businesses making acceptable returns in the future.

Instead it is to concentrate its efforts on the core Boots The Chemists business.
The decision does not impact on the established and profitable Boots Opticians which will now be managed as a significant part of the main Boots chain.

The businesses occupy 15,000 square metres of space in stores, most of which will be converted into retail trading space during 2005/6. The exit from these businesses is expected to result in exceptional costs of $£ 55 \mathrm{~m}$, of which $£ 29 \mathrm{~m}$ will be asset write-down.

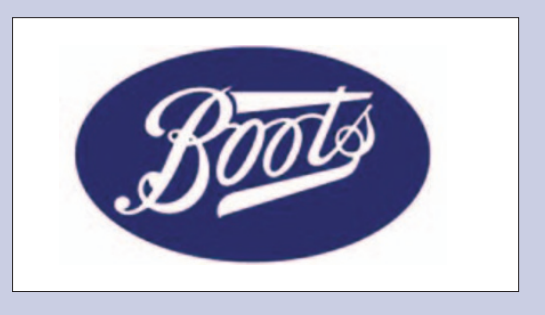




\section{DIARY}

November 2004

Building Effective Practice: Health Improvement in the Health Services Date: 03.11 .04

Venue: Edinburgh

Contact: Health Service Programme at Health Scotland

Tel: +44 (0) 1315365500

Email: margaret.richardson@health. scot.nhs.uk

\section{January 2005}

OSAP 4th Annual Intermediate-Level Infection Control and Occupational Safety and Health Course

Date: 24-27.01.04

Venue: Hyatt Regency Atlanta, Georgia Tel: 800-298-OSAP (6727) www.osap.org.

International Dental Foundation 54th International Alpine Dental Conference Date: 29.01.05-05.02.05

Venue: Hotel Annapurna, Courcheval 1850, France

Contact: Robert Wallace

Tel: +44 (0) 2072350788

Fax: +44 (0) 2072350767

Email: idf@idfdentalconference.com www.idfdentalconference.com

\section{March 2005}

83rd General Session \& Exhibition of the IADR, 34th Annual Meeting of the AADR, 29th Annual Meeting of the CADR

Date: 9-12.03.05

Venue: Baltimore Convention Centre www.dentalresearch.org

\section{Dentist breaks sailing record}

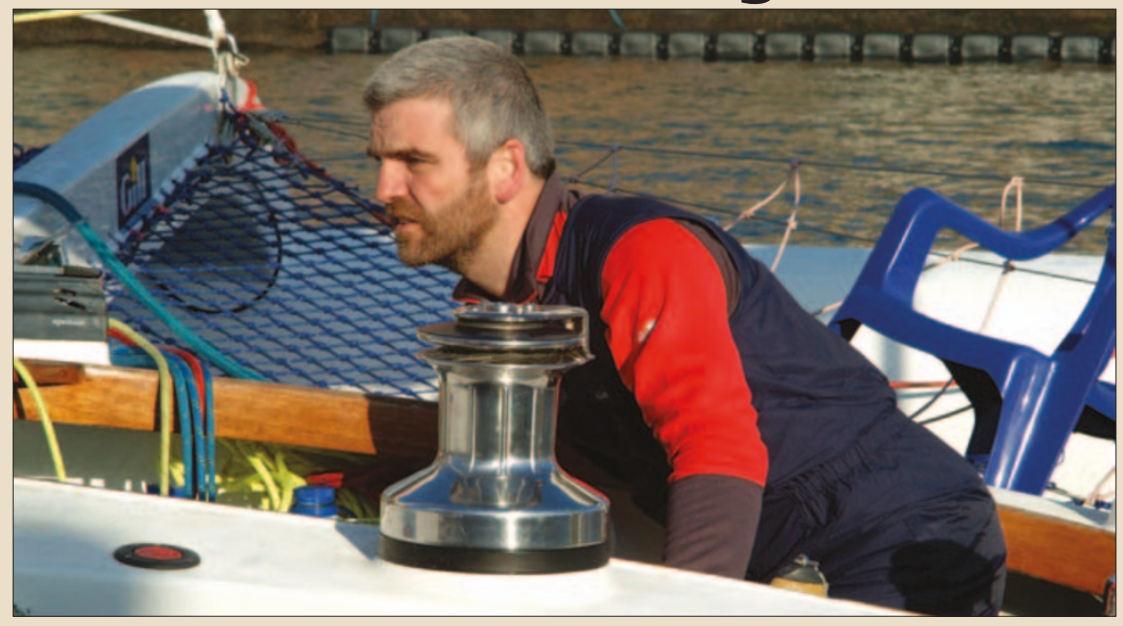

A dentist from Newcastle's Royal Victoria Infirmary has set a new world transatlantic record in sailing after beating the Bermuda to Plymouth sailing record by 14 hours.

Ross Hobson and crew members Simon Redding from Plymouth and Guy Gibbons from Southampton made the crossing in the 50ft trimaran Mollymawk and travelled 2,780 miles.

The previous record of 14 days 20 hours was set in August 1974 by ocean yachtsman Eric Tabarly in Penduick VI.

During the record breaking attempt the team overcame problems such as the port bow and dagger board breaking off during the crossing, but were able to fix them despite a lack of materials. They also faced fierce thunder storms, fantastic lightening displays and heavy rain during the journey.

The crew raised $£ 3,000$ for the charity Sail 4 Cancer which will go towards patient care and research.

Sponsors were also asked to guess the time that Dr Hobson and team would take to race across the Atlantic, and the closest entry won a day's sailing on the ocean racer Mollymawk.

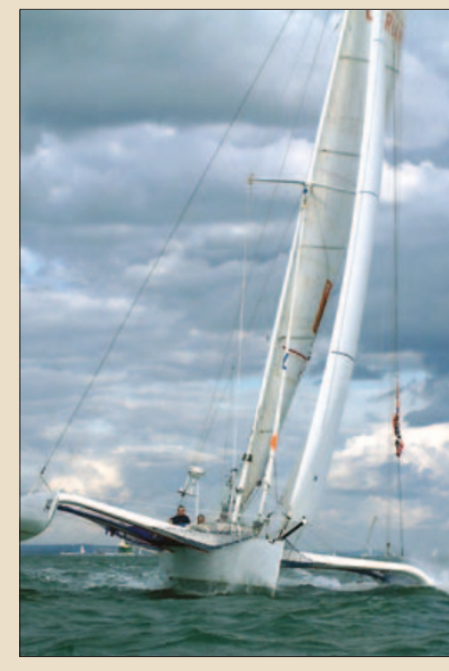

The team beat the record by 14 hours 


\section{Academy award}

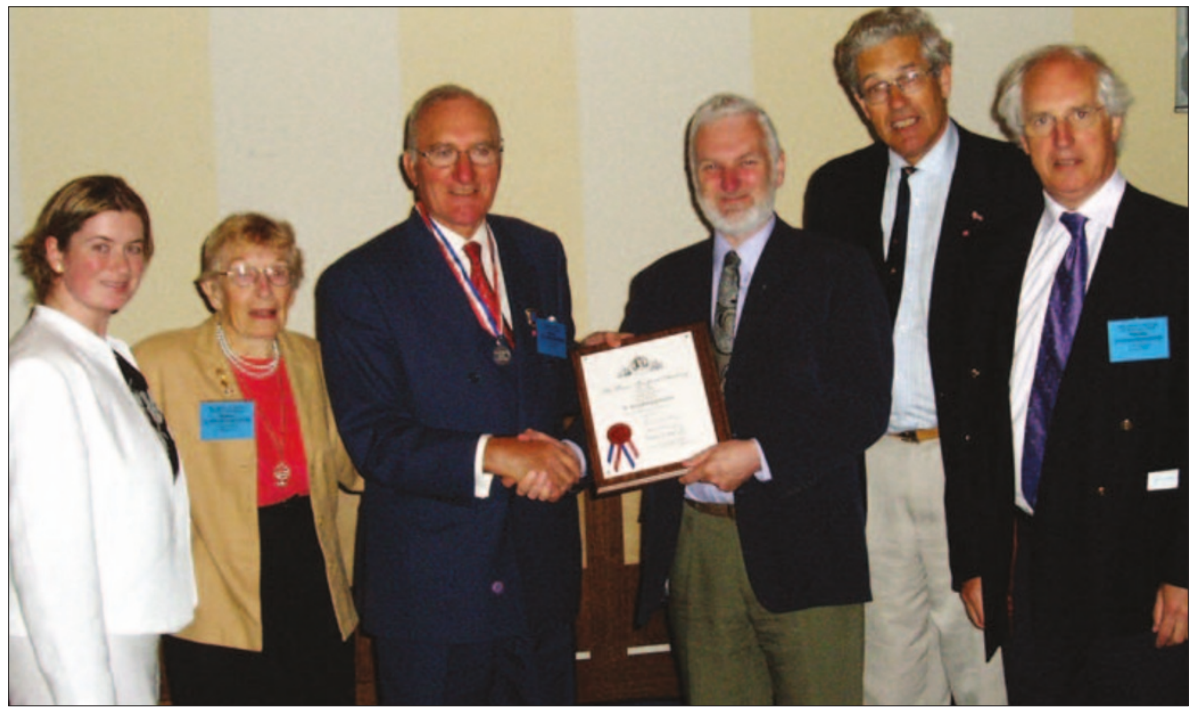

Dr Robin 0'Sullivan was recently awarded The Pierre Fauchard Academy award for exceptional contribution to dentistry. Dr O'Sullivan, a Senior Lecturer in Anatomy, in the Department of Anatomy, University College Cork, Ireland was given the award in recognition of his contribution to dental education and its assessment and his encouragement and mentoring of undergraduate and postgraduate dental students. The Pierre

Fauchard Academy is an international dental honour organisation founded in 1936 to commemorate Pierre Fauchard, the father of modern dentistry. Pictured left to right, Dr Helyn Luechauer from Hollywood, USA, Dr Gerrard McKenna from Dublin, Dr Robin 0'Sullivan from Cork, Dr Dam Backer from the Netherlands and Dr Clive Debenham from London.

\section{Using purchasing power for charity}

Online shoppers can now use their purchasing power to donate to charities such as Dentaid with a new shopping gateway called UshopUgive.com.

The stores that feature on the gateway include a huge number of well-known

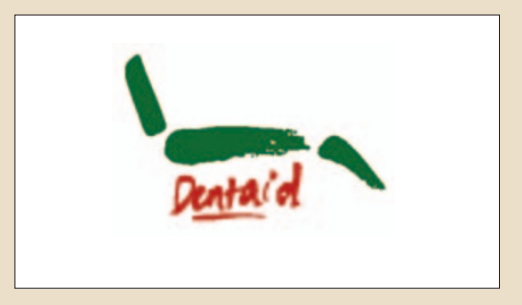

retailers who pay UshopUgive.com a sales commission of between five and $15 \%$ on everything you buy from them, via the site. Then UshopUgive.com passes a portion on to the charity you have selected and it does not cost anything extra to shop via the gateway.

Initially the gateway will give 50\% of the sales commission to the charities selected, and as purchases via the site grow, it intends to progressively increase the charities' share. It has an ultimate commitment to pass $90 \%$ of total income to the charities.

\section{Change to dental technician registration}

The GDC has made a major change to dental technician registration and has decided that registration should be compulsory for everyone directly involved in the manufacture of dental appliances. Under its old policy, unregistered dental laboratory workers would have been able to continue working but only GDC-registered technicians would have been able to sign off work leaving dental laboratories.

The new policy means that once the two-year transition to PCD registration is over, all laboratory workers with hands-on involvement in the production process will either need to be GDC-registered or on a recognised training programme. The GDC says the change in policy is in the interests of patient protection and is also based upon proposals from a collective of dental technology organisations known as the Gateway Group. The group made strong representations to the GDC over recent months in support of registration for all dental laboratory workers.

The criteria for registration as a dental technician are unaffected by the policy change. During the transitional period, technicians will be able to register on the basis of having an approved qualification or registration on the Dental Technicians Association's voluntary register or seven years' full time experience (or the part time equivalent) in the past ten years and experience of manufacturing dental appliances in one of a number of treatment areas such as prosthodontics. 